Article

\title{
Spatiotemporal Differentiation of Territorial Space Development Intensity and Its Habitat Quality Response in Northeast China
}

\author{
Zhipeng Yang ${ }^{1}\left(\mathbb{D}\right.$, Shijun Wang ${ }^{1, *}$, Meng Guo $^{1}\left(\mathbb{D}\right.$, Junfeng Tian $^{2}$ and Yingjie Zhang ${ }^{1}(\mathbb{D}$ \\ 1 School of Geographical Sciences, Northeast Normal University, Changchun 130024, China; \\ yangzp315@nenu.edu.cn (Z.Y.); guom521@nenu.edu.cn (M.G.); zhangyj486@nenu.edu.cn (Y.Z.) \\ 2 School of Public Policy and Administration, Chongqing University, Chongqing 400044, China; \\ tianjf@cqu.edu.cn \\ * Correspondence: wangsj@nenu.edu.cn
}

Citation: Yang, Z.; Wang, S.; Guo, M.; Tian, J.; Zhang, Y. Spatiotemporal Differentiation of Territorial Space Development Intensity and Its Habitat Quality Response in Northeast China. Land 2021, 10, 573. https://doi.org/10.3390/land10060573

Academic Editor: Alexis Comber

Received: 8 May 2021

Accepted: 26 May 2021

Published: 28 May 2021

Publisher's Note: MDPI stays neutral with regard to jurisdictional claims in published maps and institutional affiliations.

Copyright: (c) 2021 by the authors. Licensee MDPI, Basel, Switzerland. This article is an open access article distributed under the terms and conditions of the Creative Commons Attribution (CC BY) license (https:// creativecommons.org/licenses/by/ $4.0 /)$.

\begin{abstract}
Studying the spatiotemporal distribution characteristics of territorial space development intensity (TSDI) and its habitat quality (HQ) response is of substantial theoretical and practical significance to optimize regional development patterns and coordinate the relationship between territorial space development and eco-environmental protection. This study establishes a comprehensive assessment model across various aspects, including land, population, economy, and input, to assess the TSDI of each county in Northeast China. We used the Integrated Valuation of Ecosystem Services and Tradeoffs (InVEST) model to evaluate the HQ of each county and investigated the HQ response to TSDI. The results showed that the TSDI in Northeast China was high in the south and west, low in the north and east, and prominent in urban agglomeration areas, which increased between 2000 and 2015. The spatial pattern of HQ was low in the east and south, high in the west and north, and the HQ was degraded as a whole. Bivariate spatial autocorrelation analysis showed a significant negative spatial correlation between TSDI and HQ, and distinct patterns of local spatial agglomeration were identified. Our findings provide guidelines for territorial space planning and may offer a reference for the ecological civilization construction and the coordinated development of Northeast China.
\end{abstract}

Keywords: territorial spatial planning; ecological civilization construction; spatiotemporal relationships; response pattern; land-use optimization

\section{Introduction}

Coupled with rapidly progressing urbanization and industrialization, the territorial space development intensity (TSDI) of China has increased, and some regions have encountered problems, such as unbalanced territorial space development and serious ecological and environmental pollution [1,2]. Territorial space development and protection of the environment have become a conspicuous contradiction in ecological civilization construction in China. The Chinese government has proposed that optimizing the development pattern of territorial space should be the primary task of China's ecological civilization construction [3,4]. Further, it is necessary to clarify the TSDI and the impacts of development on ecology and the environment, which is the basis and prerequisite for enhancing the configuration of territorial space development.

TSDI is the quantitative expression for the comprehensive utilization degree of a region and reflects the degree of land utilization and human activity concentration in the region, while indicating the level of total regional development [5]. However, regarding the process of territorial space development, human disturbance to ecosystems has affected the quality of biological habitats. This has resulted in a decrease in biodiversity. In particular, the dramatic expansion of construction land has had a significant impact on habitat quality (HQ), which has led to significant challenges in biodiversity conservation [6,7]. HQ is 
closely related to biodiversity as well as ecological and environmental conditions [8]. It is also the embodiment of the ecological effect of TSDI. Therefore, under the concept of ecological civilization construction and regional coordinated development, it is urgent to measure TSDI more reasonably to clarify the current situation of territorial space development and its impact on HQ. It is also important to optimize the development direction, control the development intensity, adjust the spatial structure, and gradually form a territorial spatial development pattern with balanced population, resources, and environment alongside unified economic, social, and ecological benefits.

In recent years, territorial space development and its ecological and environmental effects have been a hot topic of research. Many studies have focused on the concept and the specific evaluation methods of TSDI. Some studies believe that TSDI reflects the ratio of construction land area to the total area of the region, and this ratio is used as an index to evaluate TSDI [9-11]. Others believe that the evaluation of regional development intensity should consider the proportion of construction land area and other land-use types along with demographic and economic factors [12-14]. Other authors in the field created an index system to evaluate land development intensity from the aspects of land structure, land benefit, and land investment [15]. In addition, new advances in technology, including remote sensing (RS) and geographic information systems (GIS), have been employed to evaluate TSDI in recent years, and the evaluation accuracy has gradually improved $[10,16]$. In particular, modern RS technology, such as the Google Earth Engine (GEE) platform, can grasp the spatiotemporal differentiation of TSDI in a timelier manner by analyzing realtime changes of land-use types on the earth's surface $[17,18]$. Furthermore, some studies have focused on the influencing factors and mechanisms of territorial space development, such as using a spatial panel-ordered response model to study the factors influencing land development intensity differences [19], utilizing GIS and logistic regression to analyze the connection between urban expansion and its associated factors $[20,21]$, and exploring the spatial differentiation mechanisms of construction land development intensity through the ordinary least squares (OLS) and geographically weighted regression (GWR) models [22]. There have also been many discussions surrounding the impact of territorial space development on the ecological environment, which have concentrated on the coupling correlation between TSDI and resource and environmental carrying capacity [23-25] and the bearing of land development intensity on biodiversity [26,27], along with the bearing of land development intensity on ecological service functions $[28,29]$.

In the research on $\mathrm{HQ}$, most scholars have evaluated $\mathrm{HQ}$ and the habitat degradation degree based on the Integrated Valuation of Ecosystem Services and Tradeoffs (InVEST) model for regions, cities, and watersheds [30-33]. On the basis of HQ evaluation, various scholars have scrutinized the impact of land-use type changes to HQ [34], the HQ response to urban expansion [35], the impact of urbanization on $\mathrm{HQ}$ in rapidly urbanized areas [8,33], and the threat of roads to regional HQ [36,37]. HQ has become a representative index for measuring the quality of the regional ecological environment. The response processes and mechanisms between $\mathrm{HQ}$ and various phenomena that reflect human activity have become more important for exploring human-land relations and issues of development and conservation [38].

Overall, current studies focus on evaluating TSDI from the single perspective of land use. However, territorial space is a comprehensive regional space, and a comprehensive evaluation of its development intensity would be relatively insufficient. Moreover, there is abundant research on the impact of land development on resources, environment carrying capacity, and ecological environment. However, there is a lack of in-depth discussion on the impact of territorial space development on HQ. Therefore, this study attempts to evaluate TSDI from a comprehensive perspective and analyze its spatial relationship with HQ.

With regard to the promotion of the Northeast China Revitalization Strategy and the construction of the Harbin-Changchun and Central and Southern Liaoning urban agglomerations, economic and social development and urbanization construction have been gradually promoted, and TSDI has increased and shown significant regional differ- 
ences in Northeast China [39,40]. In addition, Northeast China is a key ecological barrier, and the strategic position of maintaining national ecological security is vital [41,42]. The rationality of the HQ response to territorial space development is linked to the sustainable development of the region. Therefore, this study takes Northeast China as its research area and evaluates TSDI and HQ by establishing a comprehensive evaluation system and using the InVEST model. Then, it analyzes the spatial pattern, evolution process, and HQ response characteristics to TSDI in Northeast China. We hope to enrich research on the evaluation of TSDI, offer a reference for studying the HQ response to territorial space development, and provide a scientific basis for ecological civilization construction and regional high-quality development in Northeast China.

\section{Background and Theoretical Framework}

Territorial space refers to space under the jurisdiction of national sovereignty, and is the location and environment where citizens live [43]. It includes land, sea, and airspace. As a country, China enjoys a massive expanse of land. It is the most sizeable developing country in the world. There are palpable regional disparities in the development and utilization of territorial space in China. This necessitates scientific and rational spatial planning to promote its sustainable development. Therefore, the government of China has instituted numerous plans to achieve regional sustainable development. These include planning for national economic and social development, land use, and urban-rural development. Further, this includes ecological environment protection planning to guide the development and utilization of territorial space [44]. However, the execution of multiple plans results in various problems, such as contradictory planning contents, diverse planning standards, and overlapping control space. This manifests as lost land and space resources, an intensified contradiction of land development, and unbalanced regional development $[45,46]$. Due to the protracted exposure of traditional planning problems, the Chinese government has established a unified territorial space planning system. The issue of developing and protecting territorial space has received attention from all sectors of society. In 2011, China promulgated the National Main Function Zoning, which divided its territory into "optimized, key, restricted, and prohibited-development zones" based on the available carrying capacity of resources and the environment, current development intensity, and future development potential of different regions [3]. The zoning also determined specific development strategies for different types of zones [3,47]. TSDI is the basic index for "analyzing the development status of a region" [47]. Recently, the Chinese government planned to integrate national economic and social development planning, land-use planning, urban-rural development planning, and ecological environment protection planning. Such a unified territorial space planning will form a "spatial blueprint for sustainable development" [43]. Thus, TSDI has become an important component of the new land space planning system.

TSDI refers to the comprehensive utilization degree of territorial space in a region, which is usually expressed as the ratio of urban and rural construction land area to the overall area $[9,47]$. However, territorial space is a regional complex system formed by interacting resources, the environment, population, and the social economy. Its development intensity should be able to reflect the specific human-land relationship and supply-demand status of a region. The development intensity index ignores the population carried by territorial space and the economic benefits when it only focuses on the proportion of construction land [5]. The calculation of TSDI should thus consider the degree of regional space development and utilization, and its bearing intensity on the regional population, economy, and land-use scale [12]. Theoretically, population density can reflect the degree of population gathering [5], and the greater the population that gathers, the higher the intensity of territorial space development. Attributes of development are noticed in construction and cultivated land [48]. Those spaces with an above average amount of construction and cultivated land are considered seriously developed. The GDP and non-agricultural industries indicate the degree of regional economic development and the amount of industries 
with deep development that are positively correlated with the development of territorial space [49], while territorial space development requires the investment of assets as support, and the investment of fixed assets and fiscal expenditure can promote development. Therefore, the evaluation of TSDI should fully consider the relevant factors of population, land, economy, and investment within the scope of territorial space, and study the current situation of territorial space development from a comprehensive perspective.

The growth process of TSDI concerns the processes of construction land expansion, population agglomeration, increased economic aggregate, and promotion of development investment $[5,14]$. In these processes, development activities bring about fluctuations to the spatial function and structure of the territorial space, which have impacts or interferences on the ecology and environment, resulting in the degradation of $\mathrm{HQ}$ and the hindering of regional sustainable development $[26,28]$. On the one hand, the development of territorial space promotes the conversion of woodland and grassland into cultivated land and cultivated land into construction land, respectively; thus, a sizeable quota of agricultural land and natural ecological land becomes occupied. On the other hand, territorial space development adds new infrastructure, such as traffic roads, which provides convenience for deep development and breaks the original landscape pattern $[36,50]$. The evaluation of HQ must consider the following four factors: (1) the relative impact of each threat, (2) the relative sensitivity of each habitat to each threat, (3) the distance between habitats and threat sources, and (4) the degree of legal protection of land [51,52]. Therefore, the conversion of land types or the construction of infrastructure will increase the number of habitat threat sources, aggravate the degree of landscape fragmentation, and ultimately destroy HQ. HQ is degraded when TSDI increases, and it is bound to improve when TSDI decreases, that is, HQ responds to TSDI over time (Figure 1). Understanding the $\mathrm{HQ}$ response to TSDI is of great significance for constructing a coordinated relationship between development and protection.

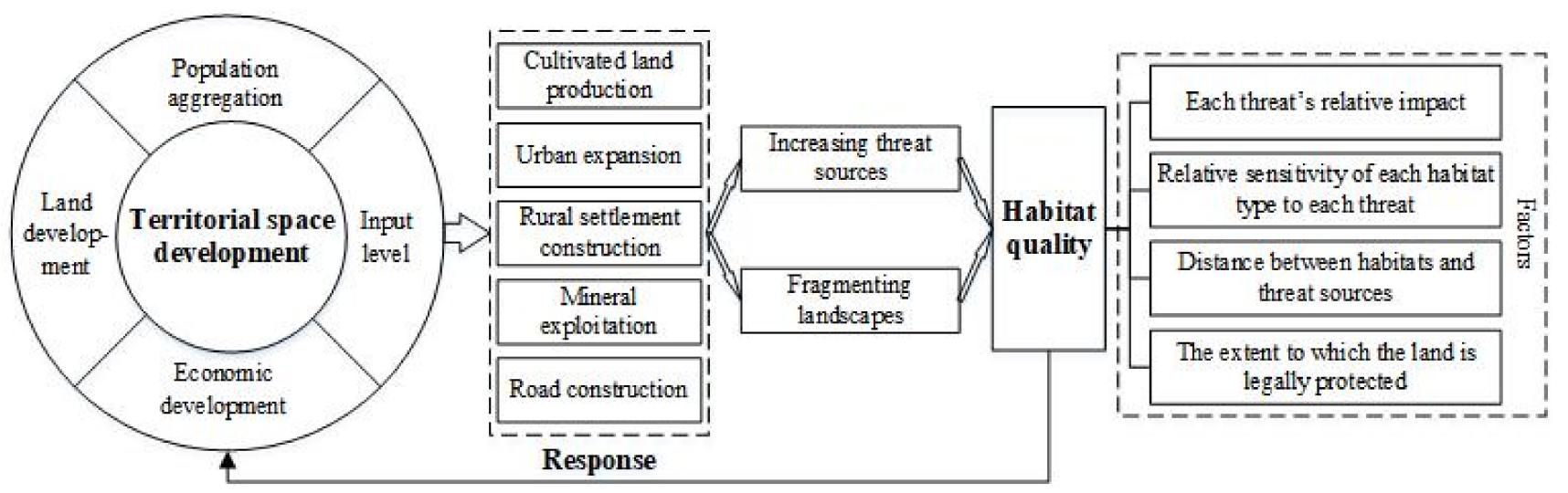

Figure 1. Mechanism of the HQ response to TSDI.

\section{Materials and Methods}

\subsection{Area of Study}

The area of study included 179 counties in Northeast China, and the scope of county space in different years was unified according to the administrative divisions of 2015 . There are various types of landforms in Northeast China, including the Greater Khingan Range and the Lesser Khingan Range in the north, the Changbai Mountains in the east, the Western Liaoning Hills in the southwest, and the Songnen Plain, the Liao River Plain and the Sanjiang Plain in the center (Figure 2). Moreover, Northeast China has a complete range of land-use types, including cultivated land, forest land, grassland, and construction land. In 2015, production in Northeast China accounted for $19.27 \%$ of the country's total grain. The forest coverage rate reached $47.80 \%$, with cultivated land and forests being the primary land-use types in the region. With advancing urbanization and the implementation of 
policies for ecological conservation, for example, restoring farmland to forest and grassland, conversions involving land-use types are relatively frequent.

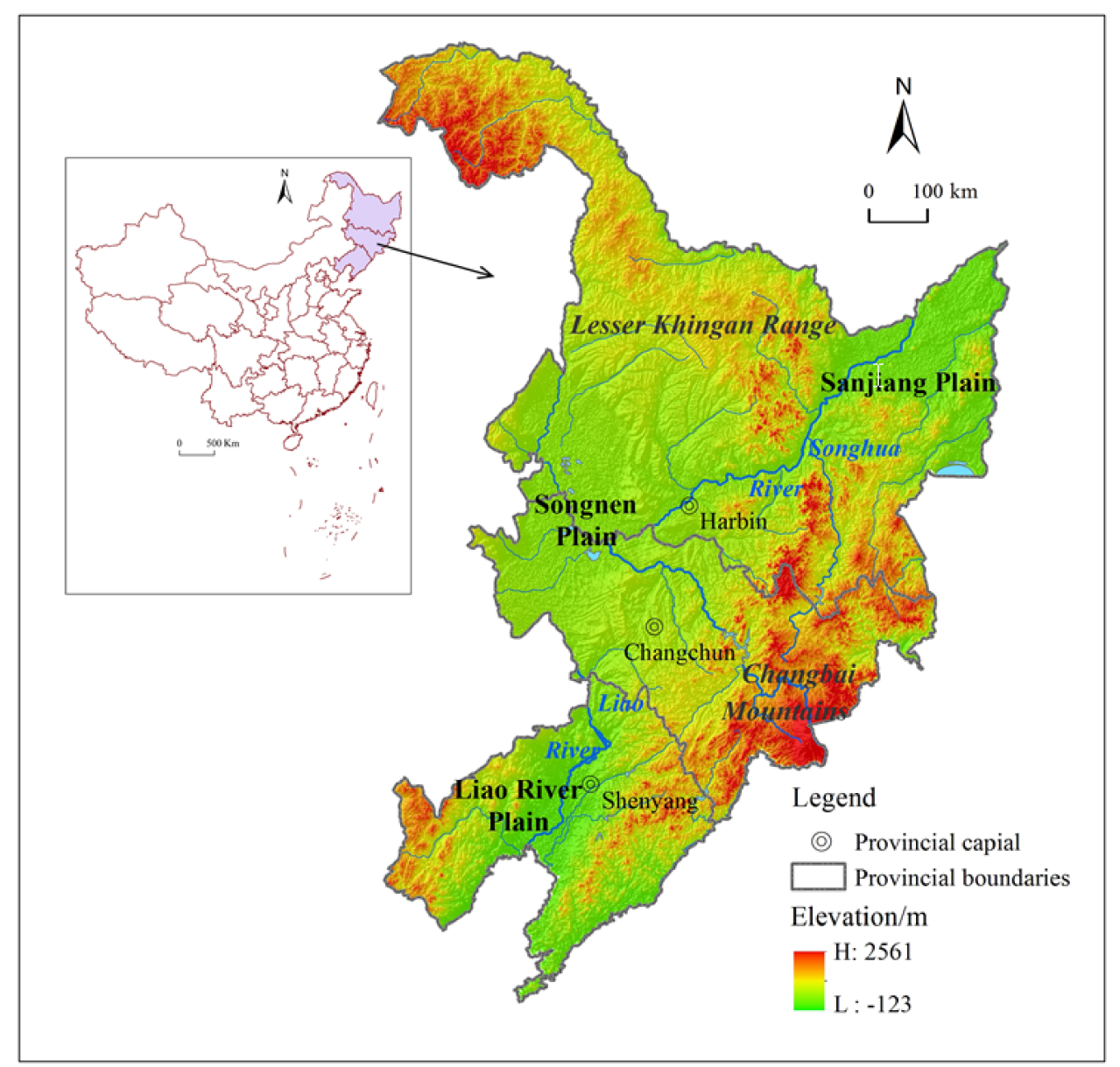

Figure 2. Overview of the study area.

In terms of social and economic development, the extent of urbanization in Northeast China increased from $46.86 \%$ in 2000 to $58.58 \%$ in 2015 . The population growth rate fluctuated in its decline from $3.20 \%$ in 2005 to $-3.60 \%$ in 2015 . The GDP per capita grew significantly from RMB 5023 in 2000 to RMB 23,123 in 2015. However, the GDP growth rate increased and then decreased from $8.49 \%$ in 2000 to $14.37 \%$ in 2006 , and then continued to decline to $4.47 \%$ in 2015 [53].

\subsection{Data Sources and Processing}

Demographic and economic data were mainly collected from the China County Statistical Yearbook $(2001,2006,2011,2016)$ and the China City Statistical Yearbook $(2001,2006$, 2011, 2016), and were partly collected from the Liaoning Statistical Yearbook, Jilin Statistical Yearbook, Heilongiiang Statistical Yearbook, and County Statistical Bulletin for corresponding years. To make the economic data of different years comparable and eliminate the impact of price changes, all economic data were deflated by the GDP deflator, with 2000 as the base. Land-use data with $100 \mathrm{~m}$ spatial resolution were obtained from the Resources and Environmental Science and Date Center, which is part of the Chinese Academy of Sciences (http:/ / www.resdc.cn, at 26 May 2016). According to the classification method for land use of the Standard of Land Use Status Classification (GB/T 21010-2007), land use was divided into six types of first-level categories: cultivated land, forest land, grassland, construction land, water areas, and unused land. The vector data for railways, expressways, national highways, and provincial highways in 2015 were provided by the National Geographic Information Resource Directory Service System (http:/ /www.webmap.cn, at 
12 September 2020), while other years were revised based on these data by referring to the China Traffic Atlas for corresponding years. These road dates were transformed into raster data matched to land-use data through the ArcGIS 10.4 conversion tool to form one of the input parameters of the InVEST model.

\subsection{Methods}

\subsubsection{TSDI Evaluation}

Referring to the current research on territorial space development $[5,15,54,55]$, this study set up an evaluation index system to assess TSDI comprehensively by selecting seven indices from four aspects: population aggregation, land development, economic development, and input level (Table 1). These indices were selected based on the principles of data accessibility and comparability, and the actual situation of territorial space development in Northeast China.

Table 1. Evaluation index system of TSDI.

\begin{tabular}{|c|c|c|c|c|}
\hline Target Layer & Standard Layer & Index Layer & Calculation of the Index & Weight \\
\hline \multirow{7}{*}{ TSDI } & Population aggregation & Population density (person $/ \mathrm{km}^{2}$ ) & Total population/total area & 0.1594 \\
\hline & \multirow{2}{*}{ Land development } & Construction land ratio $(\%)$ & Construction land area/total area & 0.1753 \\
\hline & & Cultivated land ratio $(\%)$ & Cultivated land area/total area & 0.1432 \\
\hline & \multirow[t]{2}{*}{ Economic development } & $\begin{array}{c}\text { GDP per area }(10 \text { thousand } \\
\left.\text { yuan } / \mathrm{km}^{2}\right)\end{array}$ & Total GDP / total area & 0.1334 \\
\hline & & Industry non-agricultural rate (\%) & $\begin{array}{l}\text { Total output value of secondary } \\
\text { and tertiary industries/total GDP }\end{array}$ & 0.1345 \\
\hline & \multirow{2}{*}{ Input level } & $\begin{array}{c}\text { Investment in fixed assets per area }(10 \\
\left.\text { thousand yuan } / \mathrm{km}^{2}\right)\end{array}$ & $\begin{array}{l}\text { Total investment in fixed } \\
\text { assets/construction land area }\end{array}$ & 0.1383 \\
\hline & & $\begin{array}{l}\text { Government financial expenditure per } \\
\text { area }\left(10 \text { thousand yuan } / \mathrm{km}^{2}\right)\end{array}$ & $\begin{array}{l}\text { Total government financial } \\
\text { expenditure/total area }\end{array}$ & 0.1159 \\
\hline
\end{tabular}

The units and dimensions of each index of the TSDI were different. To make each index comparable, the indices were standardized using the extremum method so that they had values ranging between 0 and 1 [56,57]. The weights of the evaluation indices were calculated using the Delphi method [58] and entropy method [59], respectively, and then combined using the weighted average weight method. The Delphi method determined the weight of the indicators by consulting experts in planning and ecological fields [58]. The entropy method was used to determine the weight by calculating the entropy value to judge the dispersion degree of the index [59]. After standardizing the indices and determining their weights, the linear weighting method was used to measure the TSDI in each region [60]. The formula to calculate TSDI is as follows:

$$
T S D I=\sum_{i=1}^{n} X_{i j} W_{i}
$$

where TSDI is the comprehensive evaluation value of territorial space development intensity; $X_{i j}$ is the standardized index; and $W_{i}$ is the weight determined by the Delphi method and the entropy method.

TSDI differences in different years were analyzed by a one-way ANOVA, followed by Tukey's post-hoc test. These statistical analysis methods were performed in the program $R$ (version 3.5.1) with the "multcomp" package.

\subsubsection{HQ Assessment}

The development of territorial space can cause an increase in the number and intensity of habitat threat sources, which in turn leads to the degradation of regional HQ [61-63]. The HQ was evaluated using the HQ module of the InVEST model. The HQ values range from 0 to 1 , where 1 indicates a habitat of the highest quality and 0 indicates a habitat of the lowest quality. The evaluation model calculates the habitat degradation degree and HQ 
based on set parameters, such as the threat source, the sensitivity of the threat source, and the distance between the habitat and threat source, reflecting the degradation status and service capacity of the regional ecosystem $[8,64]$. The first step was to calculate the degree of habitat degradation, as follows:

$$
\begin{gathered}
D_{x j}=\sum_{r=1}^{R} \sum_{y=1}^{Y_{r}} r_{y}\left(\frac{\omega_{r}}{\sum_{r=1}^{R} \omega_{r}}\right) i_{r x y} \beta_{x} S_{j r} \\
i_{r x y}=1-\left(\frac{d_{x y}}{d_{r \max }}\right) \text { (if linear) } \\
i_{r x y}=\exp \left(\frac{-2.99 d_{x y}}{d_{r \max }}\right) \text { (if exponential) }
\end{gathered}
$$

where $D_{x j}$ represents the habitat degradation degree in grid cell $x$ with habitat type $j ; R$ denotes the number of threat sources; $Y_{r}$ is the grid number on a raster map of $r ; r_{y}$ is the intensity of grid cell $y ; \omega_{r}$ indicates the weight of threat source $r ; i_{r x y}$ denotes the distance between the habitat and the threat source; $\beta_{x}$ means the anti-interference level of the grid cell $x ; S_{j r}$ represents the relative sensitivity of habitat type $j$ to the threat source $r ; d_{x y}$ is the distance between grid cells $x$ and $y$; and $d_{r \max }$ is the maximum impact distance of the threat source $r$.

Then, the formula for HQ is as follows:

$$
Q x j=H j\left[1-\left(\frac{D_{x j}^{z}}{D_{x j}^{z}+K^{z}}\right)\right]
$$

where $Q_{x j}$ is the HQ of grid cell $x$ in habitat type $j ; H_{j}$ is the habitat suitability of grid cell $x$ for habitat type $j$ and its range is $[0,1] ; K$ is a half-saturation constant; and $z$ is a scaling parameter, generally 2.5 .

Referring to the parameters recommended by the InVEST model [65] and set in the study of HQ [66,67], this study defined forest land, grassland, and water areas as habitats since they constitute the main habitats of organisms. This meant that cultivated land, rural settlements, industrial and mining land, urban land, and main traffic roads (e.g., railways, expressways, national highways, and provincial highways) were threat sources. The threat radius of cultivated land, urban land, rural settlements, industrial and mining land, and main traffic roads were set as $5,12,10,10$, and $10 \mathrm{~km}$, respectively, and the weights were 0.4 , $1.0,0.8,0.7$, and 0.8 , respectively. The distance attenuation of cultivated, urban, industrial and mining land and rural settlements on the habitat was exponential; the main traffic roads were linear [67]. In addition, the habitat suitability of each habitat type and their

\begin{tabular}{|c|c|c|c|c|c|c|}
\hline \multirow[b]{2}{*}{ Habitat Types } & \multirow{2}{*}{$\begin{array}{l}\text { Habitat } \\
\text { Suitability }\end{array}$} & \multicolumn{5}{|c|}{ Sensitivity of Habitat Types to Each Threat } \\
\hline & & $\begin{array}{c}\text { Cultivated } \\
\text { Land }\end{array}$ & $\begin{array}{l}\text { Urban } \\
\text { Land }\end{array}$ & $\begin{array}{c}\text { Rural } \\
\text { Settlements }\end{array}$ & $\begin{array}{l}\text { Industrial and } \\
\text { Mining Land }\end{array}$ & $\begin{array}{c}\text { Main Traffic } \\
\text { Roads }\end{array}$ \\
\hline Paddy field & 0.4 & 0.3 & 0.5 & 0.4 & 0.1 & 0.1 \\
\hline Dryland & 0.6 & 0.3 & 0.5 & 0.4 & 0.1 & 0.1 \\
\hline Forestland & 1.0 & 0.8 & 0.9 & 0.8 & 0.6 & 0.6 \\
\hline Bush forestland & 1.0 & 0.4 & 0.6 & 0.5 & 0.2 & 0.2 \\
\hline Open forestland & 1.0 & 0.9 & 1.0 & 0.9 & 0.7 & 0.7 \\
\hline Other forestland & 1.0 & 0.9 & 1.0 & 0.9 & 0.7 & 0.7 \\
\hline High-cover grassland & 0.8 & 0.4 & 0.6 & 0.5 & 0.2 & 0.3 \\
\hline Medium-cover grassland & 0.7 & 0.5 & 0.7 & 0.5 & 0.3 & 0.5 \\
\hline Low-cover grassland & 0.6 & 0.5 & 0.6 & 0.5 & 0.4 & 0.5 \\
\hline
\end{tabular}
sensitivity to threat sources was determined by referring to the recommended values of the model and the related literature $[8,65,68]$ (Table 2).

Table 2. Habitat suitability of each habitat type and their sensitivity to threats. 
Table 2. Cont.

\begin{tabular}{|c|c|c|c|c|c|c|}
\hline \multirow[b]{2}{*}{ Habitat Types } & \multirow[b]{2}{*}{$\begin{array}{c}\text { Habitat } \\
\text { Suitability }\end{array}$} & \multicolumn{5}{|c|}{ Sensitivity of Habitat Types to Each Threat } \\
\hline & & $\begin{array}{c}\text { Cultivated } \\
\text { Land }\end{array}$ & $\begin{array}{l}\text { Urban } \\
\text { Land }\end{array}$ & $\begin{array}{c}\text { Rural } \\
\text { Settlements }\end{array}$ & $\begin{array}{l}\text { Industrial and } \\
\text { Mining Land }\end{array}$ & $\begin{array}{c}\text { Main Traffic } \\
\text { Roads }\end{array}$ \\
\hline River canal & 0.7 & 0.7 & 0.9 & 0.8 & 0.5 & 0.5 \\
\hline Lake & 0.8 & 0.7 & 0.9 & 0.8 & 0.5 & 0.5 \\
\hline Reservoir pit & 0.7 & 0.7 & 0.9 & 0.8 & 0.6 & 0.5 \\
\hline Mudflat & 0.6 & 0.7 & 0.9 & 0.8 & 0.6 & 0.6 \\
\hline Flood land & 0.6 & 0.7 & 0.8 & 0.7 & 0.6 & 0.6 \\
\hline Saline and alkaline land & 0.4 & 0.5 & 0.6 & 0.5 & 0.5 & 0.7 \\
\hline Marsh & 0.5 & 0.5 & 0.4 & 0.2 & 0.3 & 0.7 \\
\hline
\end{tabular}

\subsubsection{Local Hot Spot Analysis}

Getis-Ord $\mathrm{Gi}^{*}$ can be performed to analyze the degree of correlation between the attributes of a unit and the same attributes of neighboring units in the study area [69-71]. This study used Getis-Ord Gi* to explore the hot and cold spots of the TSDI in Northeast China. The formula is as follows [72]:

$$
G_{i}^{*}=\frac{\sum_{j=1}^{n} w_{i, j} x_{j}-\left(\frac{1}{n} \sum_{j=1}^{n} x_{j}\right) \sum_{j=1}^{n} w_{i, j}}{\sqrt{\frac{1}{n} \sum_{j=1}^{n} x_{j}^{2}-\left(\frac{1}{n} \sum_{j=1}^{n} x_{j}\right)^{2}} \times \sqrt{\frac{1}{n-1}\left[n \sum_{j=1}^{n} w_{i, j}^{2}-\left(\sum_{j=1}^{n} w_{i, j}\right)^{2}\right]}}
$$

where $x_{j}$ is the attribute value of feature $j ; w_{i, j}$ denotes the spatial weight between features $i$ and $j$; and $n$ represents the total number of features.

The z-score and $p$-value are the output results of Getis-Ord $\mathrm{Gi}^{*}$, and they are measures of statistical significance. Higher positive $z$-scores represent hot spots where the clustering of high values is more intense. Cold spots with smaller negative z-scores represent cold spots where the clustering of low values is more intense [73]. The z-score is associated with the $p$-value. A z-score $<(-1.65)$ or $>(+1.65)$ means that there is a statistically significant cold spot or hot spot at a significance level of $p$-value $<0.10(90 \%$ confidence level). A z-score $<(-1.96)$ or $>(+1.96)$ indicates that there is a statistically significant cold spot or hot spot at a significance level of $p$-value $<0.05$ ( $95 \%$ confidence level). A $z$-score $<(-2.58)$ or $>(+2.58)$ denotes that there is a statistically significant cold spot or hot spot at a significance level of $p$-value $<0.01$ (99\% confidence level) [74,75].

\subsubsection{Bivariate Spatial Autocorrelation Analysis}

Bivariate spatial autocorrelation can reveal the correlation between the attribute values of geographic units and other attribute values in adjacent spaces [76,77]. This study explored the spatial correlation between the TSDI and HQ, using bivariate spatial autocorrelation models. Bivariate spatial autocorrelation can be divided into global spatial autocorrelation and local spatial autocorrelation [78]. Bivariate global spatial autocorrelation was described by global Moran's I, which measured the overall spatial correlation across all spatial units for the total study area [79]. Bivariate local spatial autocorrelation was measured by local Moran's I, and the aggregation and differentiation characteristics of local spatial elements were analyzed by depicting the local indicators of spatial association (LISA) map [80]. Four aggregation types were formed, including high TSDI counties with high HQ (High-High), high TSDI counties with low HQ (High-Low), low TSDI counties with high HQ (Low-High) and low TSDI counties with low HQ (Low-Low). The formulas are as follows [81,82]: 
Global Moran's I:

$$
I_{t h}=\frac{n \sum_{i=1}^{n} \sum_{j=1}^{n} w_{i j}\left(\frac{x_{t}^{i}-\bar{x}_{t}}{\sigma_{t}}\right)\left(\frac{x_{h}^{j}-\bar{x}_{h}}{\sigma_{h}}\right)}{(n-1) \sum_{i=1}^{n} \sum_{j=1}^{n} w_{i j}}
$$

Local Moran's I:

$$
I_{t h}^{i}=\frac{x_{t}^{i}-\bar{x}_{t}}{\sigma_{t}} \sum_{j=1}^{n} w_{i j} \frac{x_{h}^{j}-\bar{x}_{h}}{\sigma_{h}}
$$

where $w_{i j}$ indicates the spatial weight matrix; $x_{t}^{i}$ represents the value of attribute $t$ of unit $i$; $x_{h}^{j}$ denotes the value of attribute $h$ of unit $j ; \bar{x}_{t}$ and $\bar{x}_{h}$ are the average values of attributes $t$ and $h$, respectively; $\sigma_{t}$ and $\sigma_{h}$ indicate the variances of attributes $t$ and $h$, respectively; and $n$ is the total number of geographic units.

\section{Results}

\subsection{TSDI}

The TSDI of each county in Northeast China was calculated according to the evaluation index system of the TSDI. The value of TSDI was split into different grades, using Jenks in ArcGIS to display its spatial distribution characteristics (Figure 3). In terms of spatial patterns, TSDI in Northeast China is high in the south, low in the north, high in the west, low in the east, and prominent in urban agglomeration areas. Northeast China has various types of landforms. In the central and southern parts, the terrain is relatively flat, there is a concentration of urban and rural areas, and territorial space development is intense. The north and eastern parts contain the Greater Khingan Range, the Lesser Khingan Range, and the Changbai Mountains, with forest land as the main land type. TSDI is low in these areas, and the ecology and environment are well-maintained. By province, TSDI in the Liaoning, Jilin, and Heilongiiang Provinces decrease in turn, which is consistent with the economic development, land use, and population aggregation of each province. In addition, the TSDI of the municipal districts is obviously higher in prefecture-level cities, as they are key areas of territorial space development within prefecture-level cities.

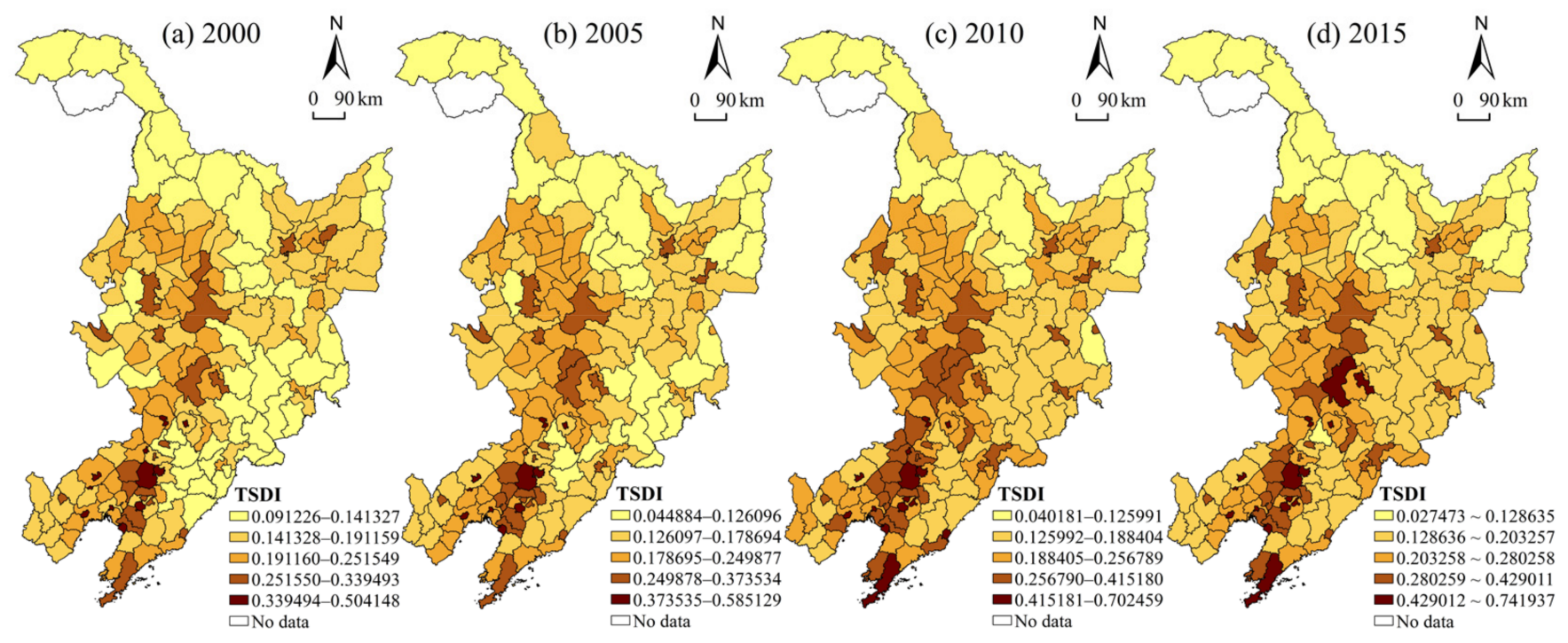

Figure 3. Spatial pattern of TSDI in Northeast China for the years (a) 2000; (b) 2005; (c) 2010; (d) 2015.

On the time scale in Figure 4 (2000-2015), the TSDI in Northeast China indicates that the development intensity increases year by year, with the most significant increase from 2005 to 2010. The overall TSDI of the three provinces in Northeast China was significantly different from 2000 to 2015 ( $p<0.05$ ); while the difference between 2000-2005 
and 2010-2015 was not significant, the difference between 2005 and 2010 was significant. From 2000 to 2005, the development in the region was relatively slow, and the overall development of territorial space was at a low level, with a small increase. From 2005 to 2010, the implementation of the Northeast Revitalization Strategy brought about rapid regional development and the industrialization level and agricultural modernization level were significantly improved, which led to the rapid development of territorial space. From 2010 to 2015, the GDP of Northeast China sharply declined from $13.70 \%$ to $4.47 \%$, regional development was under great pressure, and the increment of TSDI decreased accordingly [53]. The changing characteristics of TSDI in Liaoning Province and Jilin Province on the time scale were basically consistent with the overall characteristics of Northeast China; that is, they increased year by year with significant differences. However, TSDI in Heilongjiang Province did not differ significantly from 2005 to 2015 and decreased from 2000 to 2005. Since 2000, there have been many resource-based cities and counties in Heilongjiang Province that have undergone transformations, and the development of secondary industries has evidently reduced.

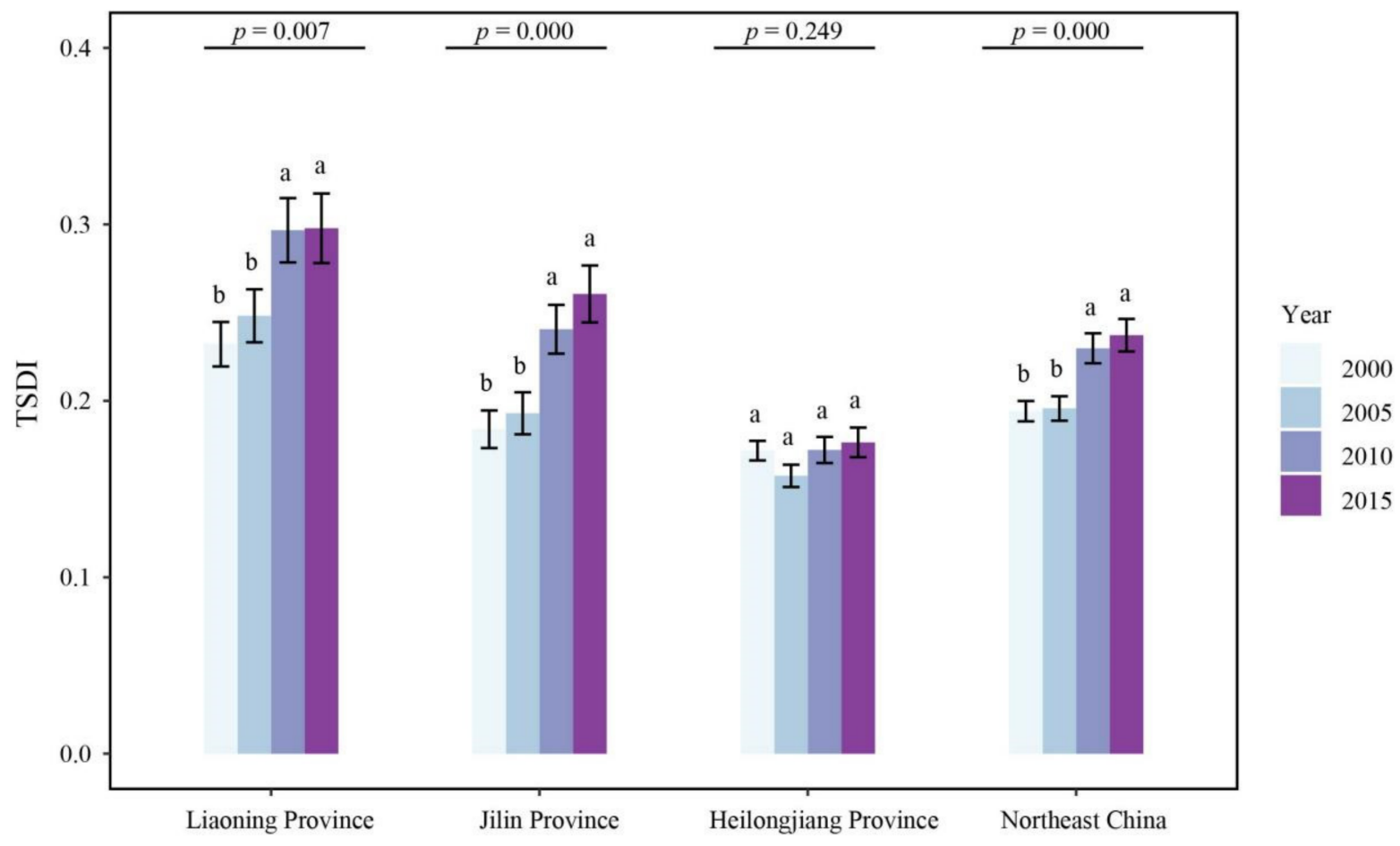

Figure 4. Changes in TSDI in Northeast China. Note: $p<0.05$ means significant difference. There is no significant difference between the same letters in different years (Tukey's post-hoc test, $p>0.05$ ).

The cold and hot spots for the TSDI of Northeast China in 2000, 2005, 2010, and 2015 were calculated using the Getis-Ord Gi* statistic in ArcGIS. Gi z-score values were divided into different grades to present the spatial heterogeneity of the cold and hot spots for the TSDI (Figure 5). The TSDI hot spots are concentrated in the Central and Southern Liaoning urban agglomeration, which is consistent with the concentration for counties with a high development intensity. The TSDI cold spots are mostly concentrated in the Greater Khingan Range and the Lesser Khingan Range areas. The counties with low development intensity are more concentrated in those areas. The TSDI hot spots are generally stable, but the scope tends to shrink. The TSDI cold spots decrease obviously in the Changbai Mountain areas and increase greatly in the Greater Khingan Range and the Lesser Khingan Range areas. Overall, the hot spots are located in the south of Northeast China and have fewer changes. The cold spots shift from southeast to north of Northeast China. 


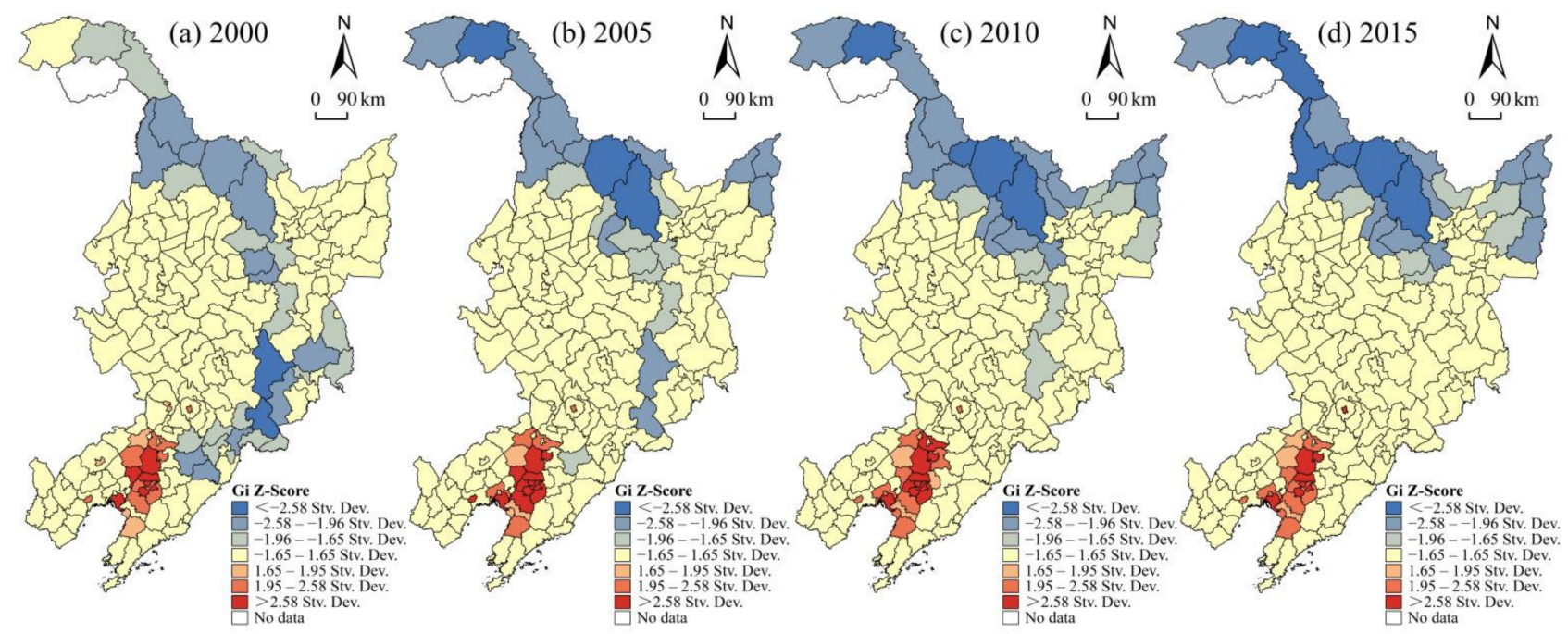

Figure 5. Distribution of cold and hot spots of TSDI in Northeast China for the years (a) 2000; (b) 2005; (c) 2010 ; (d) 2015.

\section{2. $H Q$}

The average values of HQ in each county were counted, using the spatial analyst tool in ArcGIS. HQ values were classified into five categories from low to high by Jenks in ArcGIS to obtain the spatial distribution of HQ in Northeast China in 2000, 2005, 2010, and 2015 (Figure 6). Overall, the spatial pattern of HQ in Northeast China was relatively stable in different years, and counties with the same levels of HQ were concentrated, with evident regional differentiation characteristics. The Central and Southern Liaoning urban agglomerations with the concentrated construction land, a high level of economic development, and a large degree of development constitute the regions with the lowest HQ. The HQ of counties in the Liaohe, Songnen, and Sanjiang Plains, which have vast cultivated land and frequent agricultural activities, is also low. The HQ of ecological protection areas with concentrated forest land and grassland in the Greater Khingan Range, Lesser Khingan Range, and Changbai Mountains is high. Municipal districts of most prefecture-level cities have the lowest point of HQ within the administrative region of the cities. HQ is noticeably different in different landform areas, and human activity is an important factor that affects HQ.

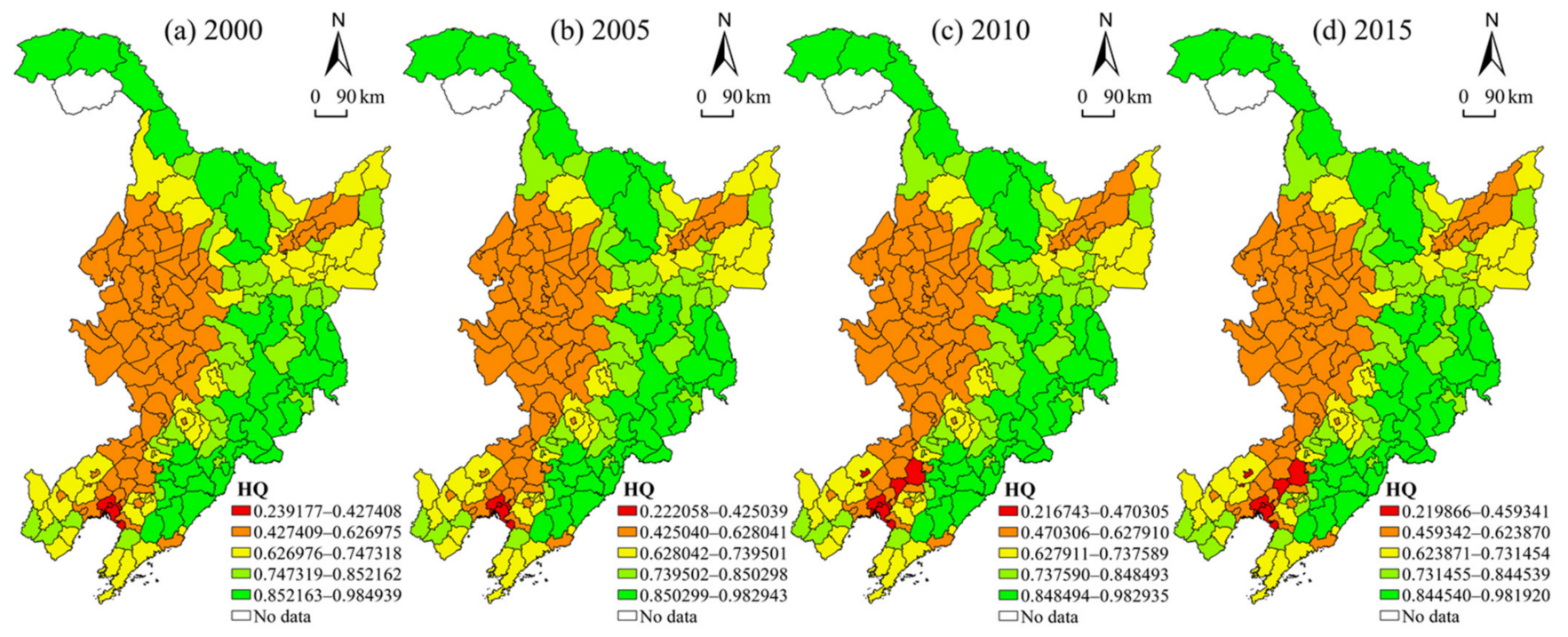

Figure 6. Spatial distribution of HQ in Northeast China for the years (a) 2000; (b) 2005; (c) 2010; (d) 2015. 
After analyzing the temporal changes, the mean value of HQ in Northeast China decreased from 0.6996 to 0.6931 between 2000 and 2015, indicating a degradation trend. From 2000 to 2005, the proportion of counties with degraded HQ was comparable to that of counties with improved HQ, and the distribution of these two types of counties was scattered. There were significant regional differences in the changes in HQ (Figure 7). From 2005 to $2010,77.65 \%$ of counties had degraded HQ, which was a significant increase. The Northeast China Revitalization Strategy has brought about rapid social and economic development, intensified human activities, and great challenges to regional $\mathrm{HQ}$, and $\mathrm{HQ}$ has faced great challenges accordingly. The newly added counties with degraded HQ were mainly concentrated in the Harbin-Changchun and Central and Southern Liaoning urban agglomerations, which have experienced explosive growth in construction land and posed serious threats to ecological land during this five-year period. From 2010 to 2015, $84.36 \%$ of the counties experienced HQ degradation, thus further reducing the overall HQ in Northeast China. In addition, the increased number of counties with degraded HQ was the highest in Heilongjiang Province, which was inevitably related to the development of the Sanjiang Plain, the intensified fragmentation of landscape patterns, and the continuous decline of ecosystem service capacity.

(a) $2000-2005$

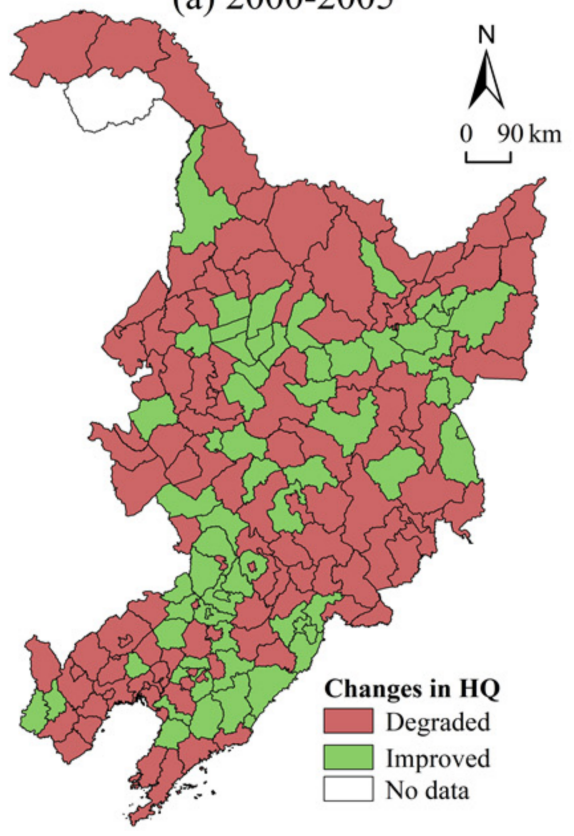

(b) $2005-2010$

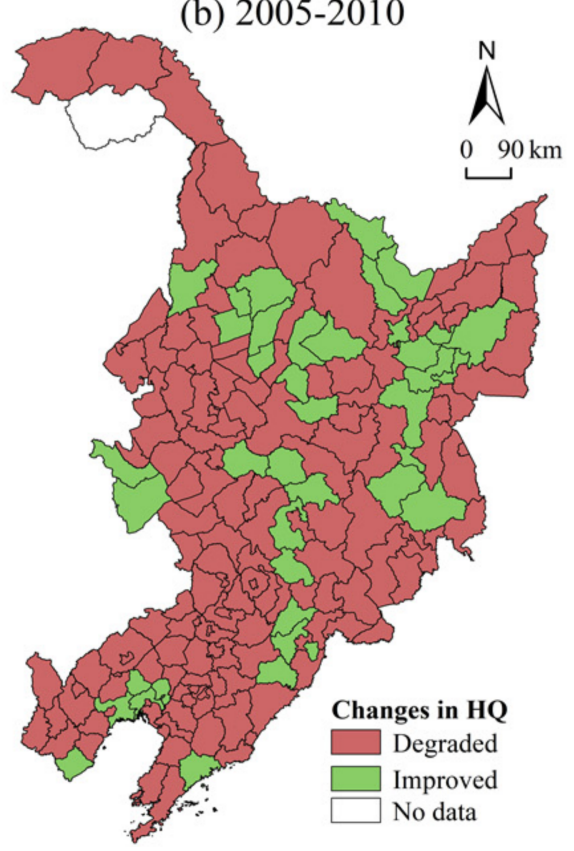

(c) $2010-2015$

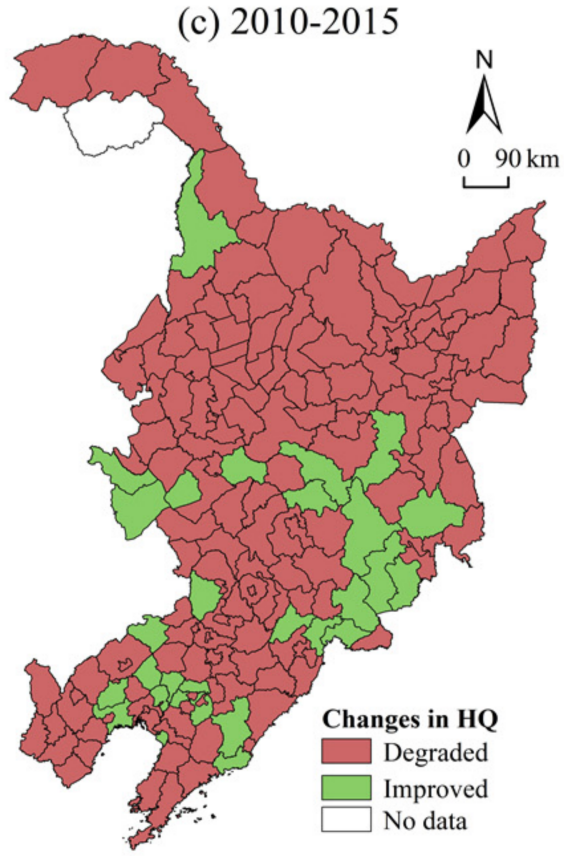

Figure 7. Changes in HQ at the county level in Northeast China during (a) 2000-2005; (b) 2005-2010; (c) $2010-2015$.

\subsection{HQ Responses to TSDI}

The global Moran's I index between TSDI and HQ in the counties was calculated using GeoDa, and the results are shown in Table 3. The index passed the significance test at the $1 \%$ level. Therefore, TSDI and HQ had a strong negative spatial correlation; that is, the higher the TSDI, the more serious the HQ degradation. The development of territorial space in Northeast China has brought more threats to $\mathrm{HQ}$, increased negative impacts on $\mathrm{HQ}$, and resulted in a decrease in HQ. In addition, the absolute value of Moran's I index decreased continuously from 2000 to 2015, indicating that the correlation between the TSDI and HQ had a slight spatial dispersion trend. 
Table 3. Parameter values of bivariate spatial correlation analysis.

\begin{tabular}{ccccc}
\hline Parameters & $\mathbf{2 0 0 0}$ & $\mathbf{2 0 0 5}$ & $\mathbf{2 0 1 0}$ & $\mathbf{2 0 1 5}$ \\
\hline Moran's I & -0.3301 & -0.2946 & -0.2420 & -0.2289 \\
Z-value & -7.9722 & -7.1254 & -6.0427 & -5.7390 \\
$p$-value & 0.0010 & 0.0010 & 0.0010 & 0.0010 \\
\hline
\end{tabular}

A bivariate LISA agglomeration map was drawn to analyze the local spatial correlation. Local spatial correlations between TSDI and HQ were split into the following types: HighHigh aggregation, High-Low aggregation, Low-High aggregation, Low-Low aggregation, and not significant (Figure 8). Except for the non-significant areas, the counties with LowHigh concentrations are dominant. These concentration areas have a low TSDI and high HQ and are distributed mostly along the Greater Khingan Range, the Lesser Khingan Range, and the Changbai Mountains. The number of counties with Low-High concentrations is generally stable from 2000 to 2015, and they comprise important ecological conservation areas in Northeast China, with concentrations of restricted and prohibited-development zones. The proportion of counties with High-Low aggregation and Low-Low aggregation is second only to those with Low-High aggregation, and the number of counties with these two aggregation types is equal. Counties with High-Low aggregation have high TSDI and low HQ and are primarily spread across the center of the Songnen Plain and the Liaohe Plain. In 2000, 2005, 2010, and 2015, there were 20, 18, 15 and 13 counties with High-Low aggregation respectively, showing a decreasing trend. In this area, there is a concentration of cities and agricultural areas, industrial and agricultural activities are frequent, and there is a negative correlation between territorial space development and habitat. Low-Low aggregation counties have low TSDI and low HQ and are mostly concentrated in the west of Jilin Province and the southwest of Heilongjiang Province. From 2000 to 2015, the distribution patterns of these counties changed only slightly. These counties have serious land salinization, poor ecology and environment, and a more serious incongruity between regional development and ecological protection. There are relatively few counties with High-High aggregation, mainly appearing sporadically in the Changbai Mountain areas but the scope is expanding. It is not difficult to notice that there are fewer counties that balance territorial space development and ecological environmental protection, but with the enhancement of people's awareness of environmental protection and the promotion of the National Main Function Zoning, there is a growing trend of counties that balance territorial space development and ecological environmental protection.

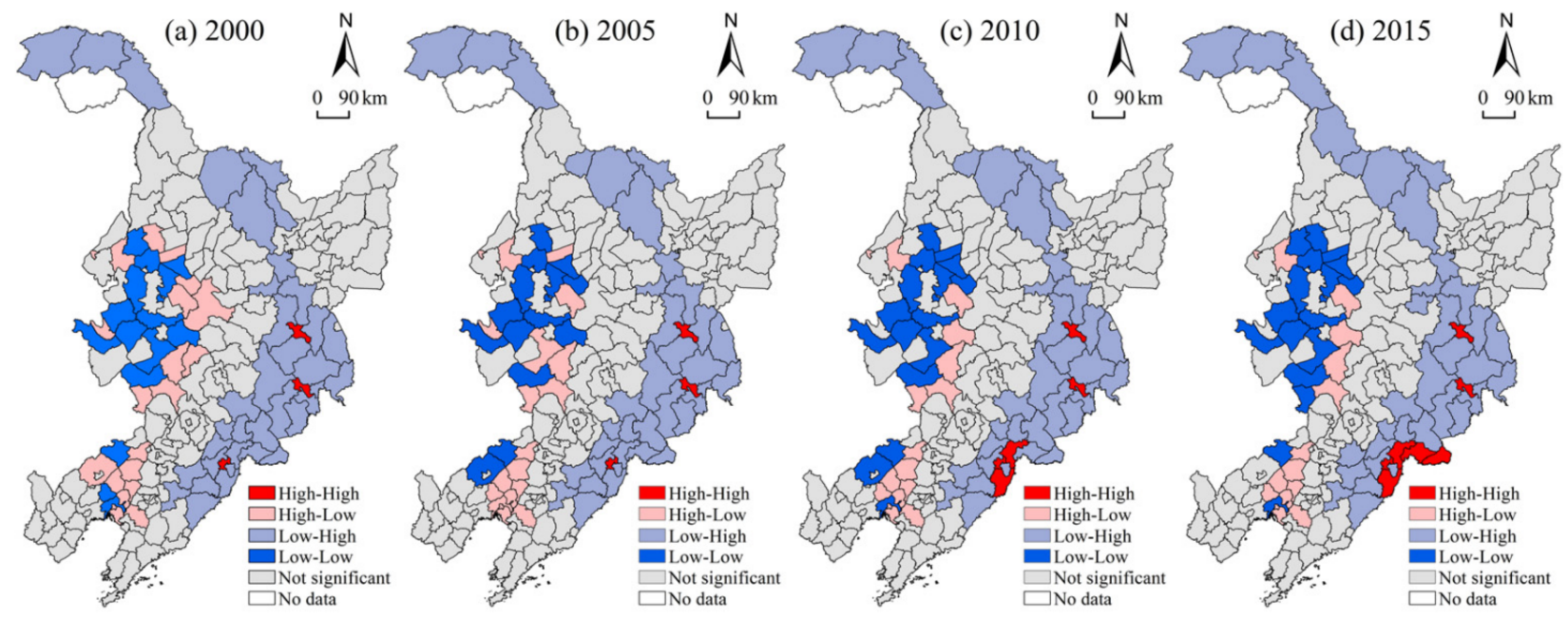

Figure 8. Spatial corresponding patterns of bivariate spatial autocorrelation between TSDI and HQ for the years (a) 2000; (b) 2005; (c) 2010; (d) 2015. 
Overall, there existed a substantial negative spatial correlation between TSDI and HQ in Northeast China from 2000 to 2015, and the HQ response to TSDI is obvious. The areas with the strongest HQ response to territorial space development in Northeast China are mostly spread across the western plains and eastern rugged mountain areas. The Songnen Plain and the Liaohe Plain areas in the west are dominated by High-Low aggregation and Low-Low aggregation, while the Greater Khingan Range, the Lesser Khingan Range, and the Changbai Mountain areas in the east are dominated by Low-High aggregation. LowHigh aggregation is the main relationship type between TSDI and HQ in Northeast China, and the scope of this aggregation area is basically stable, reflecting the important position of ecology and environmental protection in the development of counties in Northeast China.

\section{Discussion}

In recent years, China has experienced rapid urbanization and rural development, and cities and villages have been developed to varying degrees. The Chinese government is vigorously pursuing several policies to deal with contradictions in development and to promote harmonious coexistence between humans and nature. The purpose of this study was to reasonably measure TSDI and HQ and analyze the spatiotemporal relationships between them to coordinate the connection between regional growth and protection.

\subsection{Territorial Space Development Is Closely Combined with Ecology, with Implications for the Spatiotemporal Heterogeneity of the HQ Response}

This study holds that the development of territorial space involves many aspects, such as land, population, economy, and investment. Thus, it should not consider using only proportional construction land in the region. In contrast to other previous studies, we attempted to establish an analytical framework for TSDI by setting up a comprehensive evaluation index system, using four dimensions (land, population, economy, and investment) to evaluate the TSDI of each county in Northeast China. Through the assessment of this comprehensive evaluation index system, we found that TSDI in Northeast China increased year by year, and that there are obvious spatial differences. Moreover, TSDI increased most significantly between 2005 and 2010, which has also been confirmed by many previous studies [22,83-85]. The pattern of territorial space development is directly related to resource endowment, economic development, and national strategy [47]. Northeast China has a massive expanse of land, and there is great variance in the resource endowments and ranges of economic development among the different counties, which also causes regional differences in spatial land development patterns. The Chinese government began implementing the Northeast Revitalization Strategy at the end of 2003 to vigorously support the development of Northeast China. The key period of the Northeast's revitalization and development was between 2005 and 2010, and territorial space developed rapidly [53]. After this period, development faced great pressure, as it was restricted by factors such as insufficient innovation, and the TSDI increased slowly.

The urbanization and accelerated development of territory in China has brought about a series of resource and environmental problems. Consistent with many existing studies, our study also concluded that the development of territorial space has caused the degradation of regional ecology and environment [28]. However, in contrast to previous studies, our study focused on the spatial response of HQ to territorial space development. Currently, there is no consistent method for assessing HQ. Therefore, by considering the impact of human activity on habitats in the process of territorial space development, we employed the use of the InVEST model to measure regional HQ in this study [33]. The InVEST model is employed worldwide to assess regional HQ and is proved to be reliable $[7,34,86]$. This would certainly increase the scientific validity of our study.

In addition, bivariate spatial autocorrelation was used to reveal the negative spatial correlation between TSDI and HQ and the spatial difference of the HQ response to TSDI, which provides a new perspective for studying the relationship between landscape patterns and ecosystem services in the process of territorial space development. Bivariate spatial autocorrelation has been widely used to explore the correlation between two sys- 
tems. Scholars from different countries and regions used this method to analyze different problems, such as the relationship between air pollution and allergic diseases [87], spatial relationship between economic growth and renewable energy consumption [88]. The TSDI and $\mathrm{HQ}$ are interactive variables. It is reasonable to use bivariate spatial autocorrelation to analyze the spatial relationship between them, and it is also applicable worldwide. Exploring the HQ response to territorial space development could help society better understand the impact of human activity on biodiversity and ecological service levels [8].

\subsection{Policy Implications for Territorial Space Development in Northeast China}

Northeast China has relatively rich cultivated land and ecological resources. Under the development strategy for food and ecological security, the relationship between development and protection in this area is important, and there is a large space for optimizing the relationship between humans and land [89]. By analyzing the spatiotemporal variation of TSDI and the HQ response to TSDI in Northeast China, we can clarify the impact of unreasonable land use on $\mathrm{HQ}$ and advance the understanding of optimizing territorial space development and improve the ecological environment quality. We provide the proposals below to help land management and regional development.

First, the difference between TSDI and its relationship with HQ can guide land management in Northeast China. In the context of the irreversible trend of population urbanization, the government should formulate specific land-control policies to strictly control the scale of construction land, improve the level of land intensive and economical use, and rationally plan infrastructure construction. The strict protection policies for ecological land should also be implemented to minimize the number of habitat threats and prevent further fragmentation of the ecological landscape. Second, the four types of clustering patterns (i.e., High-High, High-Low, Low-High, Low-Low) between TSDI and HQ can be combined with the development requirements of priority, key, restricted, and prohibited-development zones in the National Main Function Zoning to scientifically guide the development of a county. Areas with high TSDI and high HQ should promote the process of industrialization and urbanization. Areas with high TSDI and low HQ should alter their ideas regarding development, and any regional development activities in these areas should be subject to strict review. There are ecologically advantageous areas where TSDI is low and HQ is high. Development and construction activities in areas that are not related to conservation should be eliminated. Ecological restoration projects should be prioritized in areas with low TSDI and low HQ [90]. Additionally, attention should be afforded to the development and protection of key regions. For example, the TSDI of counties in the Changbai Mountain area has increased significantly, and the development intensity has gradually changed from cold spots to sub-cold spots in Northeast China. When developing tourism and the forest economy, it is imperative to reinforce the investment in ecological and environmental protection in these counties to obtain development benefits and avoid sacrificing habitats. The counties to the west of Jilin Province and southwest of Heilongjiang Province are ecologically fragile areas with problems of low development and low HQ. These counties should actively implement projects that connect rivers and lakes to enhance landscape connectivity [91], promote ecological management and restoration, and improve regional ecology and the environment.

\subsection{Limitations and Prospects for Further Study}

This study is not without some limitations. First, we focused on the objectivity of the evaluation index system when assessing TSDI, but some subjectivity is inevitable. Second, considering the availability of data and the analysis at equal annual intervals, we used data for 2000, 2002, 2010, and 2015. Future studies should supplement the recent data and lengthen the time span to better discover changes in territorial space development and the related ecological effects. Finally, the connotations of TSDI and HQ are profound, so it is a relatively grand systematic project to attempt to study the relationship and coordinated development between them. Territorial space is a complex and integrated area, and 
achieving overall coordination between its socioeconomic development and environmental protection is a gradual process. In this study, the HQ response to TSDI constitutes a relatively preliminary study of the relationship between them. Our selection of habitat threat sources also only considered the most direct impacts of territorial development. Thus, the HQ response under multiple ecological functions and the comprehensive ecological effects of territorial space development should be considered directions for improvement and in-depth study in the future.

\section{Conclusions}

This study established a comprehensive evaluation system for TSDI and evaluated and analyzed its spatiotemporal variation characteristics of counties in Northeast China. The HQ of counties was evaluated using the InVEST model, and the HQ response pattern to TSDI was further discussed.

The main conclusions are as follows: (1) TSDI in Northeast China was higher in the south, lower in the north, higher in the west, and lower in the east, and prominent in urban agglomeration areas, which grew continuously during the study period. The growth was most obvious at the initial stage of implementation of the Northeast Revitalization Strategy. (2) The HQ of counties in Northeast China was lower in the east, higher in the west, lower in the south, and higher in the north. During the study period, the proportion of counties with degraded HQ increased, and the challenges of regional ecological and environmental protection increased. (3) There was a significant negative spatial correlation between TSDI and HQ in Northeast China. The Low-High aggregation type was the main relationship between the two and was mainly distributed in mountainous areas with better ecological protection. However, there were some counties with the Low-Low aggregation type in ecologically fragile areas, and the uncoordinated problems between space development and ecological protection in these regions were severe, which should be afforded more attention in the future.

Our study not only considered the influence of the construction land on TSDI, as in previous studies, but also increased the indicators of population, economy, and investment to evaluate the current situation of TSDI in Northeast China more scientifically and comprehensively. In addition, we focused on the spatial response relationship between HQ and TSDI to integrate territorial space development with ecology. Our study can improve the evaluation of TSDI and provide methodological references and new perspectives for studying the relationship between development activities and ecological levels. The findings of this study are important for understanding the synergistic effects between human activity and ecological systems and can provide practical guidance for territorial space planning. We suggest that the TSDI should be controlled reasonably so as to promote the coordinated and sustainable development of TSDI and HQ. In addition, the government should arrange differentiated development strategies and land management measures based on the regional differentiation of TSDI and HQ when formulating territorial space planning.

Author Contributions: Conceptualization, Z.Y. and S.W.; methodology, Z.Y.; data curation, S.W. and J.T.; writing - original draft preparation, Z.Y.; writing—review and editing, S.W., M.G. and J.T.; visualization, Z.Y. and Y.Z.; supervision, S.W.; project administration, S.W.; funding acquisition, S.W. All authors have read and agreed to the published version of the manuscript.

Funding: This research was funded by the National Natural Science Foundation of China (Grant No. 41630749) and the Foundation of the Education Department of Jilin Province, China (Grant No. JJKH20211290KJ).

Institutional Review Board Statement: Not applicable.

Informed Consent Statement: Not applicable.

Data Availability Statement: Not applicable.

Acknowledgments: We greatly thank the reviewers and editors for their constructive suggestions and comments. 
Conflicts of Interest: The authors declare no conflict of interest.

\section{References}

1. You, H.; Yang, X. Urban expansion in 30 megacities of China: Categorizing the driving force profiles to inform the urbanization policy. Land Use Policy 2017, 68, 531-551. [CrossRef]

2. Xiong, N.; Wong, S.W.; Ren, Y.; Shen, L. Regional Disparity in Urbanizing China: Empirical Study of Unbalanced Development Phenomenon of Towns in Southwest China. J. Urban Plan. Dev. 2020, 146, 05020013. [CrossRef]

3. Fan, J.; Wang, Y.; Wang, C.; Chen, T.; Jin, F.; Zhang, W.; Li, L.; Xu, Y.; Dai, E.; Tao, A.; et al. Reshaping the Sustainable Geographical Pattern: A Major Function Zoning Model and Its Applications in China. Earths Future 2019, 7, 25-42. [CrossRef]

4. Liu, Y.; Li, J.; Yang, Y. Strategic adjustment of land use policy under the economic transformation. Land Use Policy 2018, 74, 5-14 [CrossRef]

5. Kong, X.; Jiang, X.; Liu, Y.; Jin, Z. Spatiotemporal Coupling Between Territorial Space Development Intensity and Resource Environmental Carrying Capacity and Its Planning Implications: A Case Study of Jiangsu Province. China Land Sci. 2020, 34, 10-17.

6. Dadashpoor, H.; Azizi, P.; Moghadasi, M. Land use change, urbanization, and change in landscape pattern in a metropolitan area. Sci. Total Environ. 2019, 655, 707-719. [CrossRef]

7. Sallustio, L.; De Toni, A.; Strollo, A.; Di Febbraro, M.; Gissi, E.; Casella, L.; Geneletti, D.; Munafo, M.; Vizzarri, M.; Marchetti, M. Assessing habitat quality in relation to the spatial distribution of protected areas in Italy. J. Environ. Manag. 2017, 201, 129-137. [CrossRef]

8. Bai, L.; Xiu, C.; Feng, X.; Liu, D. Influence of urbanization on regional habitat quality:a case study of Changchun City. Habitat Int. 2019, 93, 102042. [CrossRef]

9. Huang, X.; Huang, X.; Liu, M.; Wang, B.; Zhao, Y. Spatial-temporal Dynamics and Driving Forces of Land Development Intensity in the Western China from 2000 to 2015. Chin. Geogr. Sci. 2020, 30, 16-29. [CrossRef]

10. Wellmann, T.; Haase, D.; Knapp, S.; Salbach, C.; Selsam, P.; Lausch, A. Urban land use intensity assessment: The potential of spatio-temporal spectral traits with remote sensing. Ecol. Indic. 2018, 85, 190-203. [CrossRef]

11. Zhou, K.; Fan, J.; Sheng, K. Research on methods and approaches of spatial governances. Geogr. Res. 2019, 38, $2527-2540$.

12. Erb, K.H.; Haberl, H.; Jepsen, M.R.; Kuemmerle, T.; Lindner, M.; Muller, D.; Verburg, P.H.; Reenberg, A. A conceptual framework for analysing and measuring land-use intensity. Curr. Opin. Environ. Sustain. 2013, 5, 464-470. [CrossRef]

13. Felipe-Lucia, M.R.; Soliveres, S.; Penone, C.; Fischer, M.; Ammer, C.; Boch, S.; Boeddinghaus, R.S.; Bonkowski, M.; Buscot, F.; Fiore-Donno, A.M.; et al. Land-use intensity alters networks between biodiversity, ecosystem functions, and services. Proc. Natl. Acad. Sci. USA 2020, 117, 28140-28149. [CrossRef]

14. Xu, F.; Wang, Z.; Chi, G.; Zhang, Z. The impacts of population and agglomeration development on land use intensity: New evidence behind urbanization in China. Land Use Policy 2020, 95, 104639. [CrossRef]

15. Gong, J.; Chen, W.; Liu, Y.; Wang, J. The intensity change of urban development land: Implications for the city master plan of Guangzhou, China. Land Use Policy 2014, 40, 91-100. [CrossRef]

16. Di, X.; Hou, X.; Wang, Y.; Wu, L. Spatial-temporal Characteristics of Land Use Intensity of Coastal Zone in China During 2000-2010. Chin. Geogr. Sci. 2015, 25, 51-61. [CrossRef]

17. Ruth, D.; Frédéric, A.; Sandra, B.; Martin, H. Earth observations for estimating greenhouse gas emissions from deforestation in developing countries. Environ. Sci. Policy 2007, 10, 385-394.

18. Zurqani, H.A.; Post, C.J.; Mikhailova, E.A.; Allen, J.S. Mapping Urbanization Trends in a Forested Landscape Using Google Earth Engine. Remote Sens. Earth Syst. Sci. 2019, 2, 173-182. [CrossRef]

19. Ferdous, N.; Bhat, C.R. A spatial panel ordered-response model with application to the analysis of urban land-use development intensity patterns. J. Geogr. Syst. 2013, 15, 1-29. [CrossRef]

20. Wang, X.; Wang, S.; Song, Y.; Hu, H. Space Recognition and Influence Mechanism of Urban Construction Land Evolution of Changchun City. Sci. Geogr. Sin. 2015, 35, 873-881.

21. Azhdari, A.; Sasani, M.A.; Soltani, A. Exploring the relationship between spatial driving forces of urban expansion and socioeconomic segregation: The case of Shiraz. Habitat Int. 2018, 81, 33-44. [CrossRef]

22. Liu, Y.; Yu, H.; Liu, D.; Zhu, L. Spatial differentiation mechanisms of the pattern evolution of construction land development intensity in Northeast China. Acta Geogr. Sin. 2018, 73, 818-831.

23. Brown, K.; Turner, R.K.; Hameed, H.; Bateman, I. Environmental carrying capacity and tourism development in the Maldives and Nepal. Environ. Conserv. 1997, 24, 316-325. [CrossRef]

24. Xie, X.T.; Li, X.S.; He, W.K. A Land Space Development Zoning Method Based on Resource-Environmental Carrying Capacity: A Case Study of Henan, China. Int. J. Environ. Res. Public Health 2020, 17, 900. [CrossRef]

25. Yan, H.; Liu, F.; Liu, J.; Xiao, X.; Qin, Y. Status of land use intensity in China and its impacts on land carrying capacity. J. Geogr. Sci. 2017, 27, 387-402. [CrossRef]

26. van Diggelen, R.; Sijtsma, F.J.; Strijker, D.; van den Burg, J. Relating land-use intensity and biodiversity at the regional scale. Basic Appl. Ecol. 2005, 6, 145-159. [CrossRef]

27. Van Meerbeek, K.; Helsen, K.; Hermy, M. Impact of land-use intensity on the conservation of functional and phylogenetic diversity in temperate semi-natural plant communities. Biodivers. Conserv. 2014, 23, 2259-2272. [CrossRef] 
28. Xu, Y.; Tang, H.; Wang, B.; Chen, J. Effects of land-use intensity on ecosystem services and human well-being: A case study in Huailai County, China. Environ. Earth Sci. 2016, 75, 416. [CrossRef]

29. Lopes, L.F.G.; Bento, J.; Cristovao, A.; Baptista, F.O. Exploring the effect of land use on ecosystem services: The distributive issues. Land Use Policy 2015, 45, 141-149. [CrossRef]

30. Lyu, R.; Zhang, J.; Xu, M.; Li, J. Impacts of urbanization on ecosystem services and their temporal relations: A case study in Northern Ningxia, China. Land Use Policy 2018, 77, 163-173. [CrossRef]

31. Moreira, M.; Fonseca, C.; Vergilio, M.; Calado, H.; Gil, A. Spatial assessment assessment of habitat conservation status in a Macaronesian island based on the InVEST model: A case study of Pico Island (Azores, Portugal). Land Use Policy 2018, 78, 637-649. [CrossRef]

32. Upadhaya, S.; Dwivedi, P. Conversion of of forestlands to blueberries: Assessing implications for habitat quality in Alabaha river watershed in Southeastern Georgia, United States. Land Use Policy 2019, 89, 104229. [CrossRef]

33. Zhu, C.; Zhang, X.; Zhou, M.; He, S.; Gan, M.; Yang, L.; Wang, K. Impacts of urbanization and landscape pattern on habitat quality using OLS and GWR models in Hangzhou, China. Ecol. Indic. 2020, 117, 106654. [CrossRef]

34. Sharma, R.; Nehren, U.; Rahman, S.A.; Meyer, M.; Rimal, B.; Seta, G.A.; Baral, H. Modeling Land Use and Land Cover Changes and Their Effects on Biodiversity in Central Kalimantan, Indonesia. Land 2018, 7, 57. [CrossRef]

35. Dai, Y.; Li, J.; Yang, J. Spatiotemporal responses of habitat quality to urban sprawl in the Changsha metropolitan area. Prog. Geogr. 2018, 37, 1340-1351.

36. Zhou, X.; Xiao, L.; Lu, X.; Sun, D. Impact of road transportation development on habitat quality in economically developed areas: A case study of Jiangsu Province, China. Growth Chang. 2020, 51, 852-871. [CrossRef]

37. Whittington, J.; Low, P.; Hunt, B. Temporal road closures improve habitat quality for wildlife. Sci. Rep. 2019, 9, 3772. [CrossRef]

38. Kija, H.K.; Ogutu, J.O.; Mangewa, L.J.; Bukombe, J.; Verones, F.; Graae, B.J.; Kideghesho, J.R.; Said, M.Y.; Nzunda, E.F. SpatioTemporal Changes in Wildlife Habitat Quality in the Greater Serengeti Ecosystem. Sustainability 2020, 12, 2440. [CrossRef]

39. Deng, Y.; Qi, W.; Fu, B.; Wang, K. Geographical transformations of urban sprawl: Exploring the spatial heterogeneity across cities in China 1992-2015. Cities 2020, 105, 102415. [CrossRef]

40. Wang, J.; Du, D. The Evolution of Economic Development Level in Northeast China and Its Spatial Differentiation Mode Scince 2003. Sci. Geogr. Sin. 2016, 36, 1320-1328.

41. Wang, J.; He, T.; Lin, Y. Changes in ecological, agricultural, and urban land space in 1984-2012 in China: Land policies and regional social-economical drivers. Habitat Int. 2018, 71, 1-13. [CrossRef]

42. Xia, H.; Zhang, W.; Wang, H.; Peng, H.; Zhang, Z.; Ke, Q.; Bu, S. Spatial -temporal patterns and characteristics of ecological function between 2009 and 2015 in China. Ecol. Indic. 2020, 116, 106478. [CrossRef]

43. Liu, Y.; Zhou, Y. Territory spatial planning and national governance system in China. Land Use Policy 2021, 102, 105288. [CrossRef]

44. $\mathrm{Hu}, \mathrm{R}$. Planning for growth: Urban and regional planning in China. Plan. Perspect. 2016, 31, 152-155. [CrossRef]

45. Hu, Y.; Roo, G.D.; Lu, B. 'Communicative turn' in Chinese spatial planning? Exploring possibilities in Chinese contexts. Cities 2013, 35, 42-50. [CrossRef]

46. Kong, W.; Liu, H.; Fan, J. The Features and Causes of Spatial Planning Conflicts in China: Taking Urban Planning and Land-Use Planning as Examples. Chin. J. Urban Environ. Stud. 2019, 7, 18. [CrossRef]

47. Fan, J.; Sun, W.; Zhou, K.; Chen, D. Major Function Oriented Zone: New method of spatial regulation for reshaping regional development pattern in China. Chin. Geogr. Sci. 2012, 22, 196-209. [CrossRef]

48. Twisa, S.; Buchroithner, M.F. Land-Use and Land-Cover (LULC) Change Detection in Wami River Basin, Tanzania. Land 2019, 8, 136. [CrossRef]

49. Wang, Z. Land Spatial Development Based on Carrying Capacity, Land Development Potential, and Efficiency of Urban Agglomerations in China. Sustainability 2018, 10, 4701. [CrossRef]

50. Wu, C.F.; Lin, Y.P.; Chiang, L.C.; Huang, T. Assessing highway's impacts on landscape patterns and ecosystem services: A case study in Puli Township, Taiwan. Landsc. Urban Plan. 2014, 128, 60-71. [CrossRef]

51. Xu, L.; Chen, S.S.; Xu, Y.; Li, G.; Su, W. Impacts of Land-Use Change on Habitat Quality during 1985-2015 in the Taihu Lake Basin. Sustainability 2019, 11, 3513. [CrossRef]

52. Yi, H.; Guneralp, B.; Kreuter, U.P.; Guneralp, I.; Filippi, A.M. Spatial and temporal changes in biodiversity and ecosystem services in the San Antonio River Basin, Texas, from 1984 to 2010. Sci. Total Environ. 2018, 619, 1259-1271. [CrossRef]

53. Tian, J.; Wang, B.; Zhang, C.; Li, W.; Wang, S. Mechanism of regional land use transition in underdeveloped areas of China: A case study of northeast China. Land Use Policy 2020, 94, 104538. [CrossRef]

54. Nan, L.; Zhao, J.; Lyu, M. Exploration of Land Development Intensity Index of Port Container Logistics Park Based on Quantitative Algorithm and Pent Analysis Method. Pol. Marit. Res. 2018, 25, 61-67.

55. Tang, C.; Sun, W. Comprehensive Evaluation of Land Spatial Development Suitability of the Yangtze River Basin. Acta Geogr. Sin. 2012, 67, 1587-1598.

56. Zhang, R.; Jiang, G.; Zhang, Q. Does urbanization always lead to rural hollowing? Assessing the spatio-temporal variations in this relationship at the county level in China 2000-2015. J. Clean. Prod. 2019, 220, 9-22. [CrossRef]

57. Koschke, L.; Fuerst, C.; Frank, S.; Makeschin, F. A multi-criteria approach for an integrated land-cover-based assessment of ecosystem services provision to support landscape planning. Ecol. Indic. 2012, 21, 54-66. [CrossRef] 
58. Walters, D.; Kotze, D.C.; Rebelo, A.; Pretorius, L.; Job, N.; Lagesse, J.V.; Riddell, E.; Cowden, C. Validation of a rapid wetland ecosystem services assessment technique using the Delphi method. Ecolo. Indic. 2021, 125, 107511.

59. Ludovisi, A. Effectiveness of entropy-based functions in the analysis of ecosystem state and development. Ecol. Indic. 2014, 36, 617-623. [CrossRef]

60. Zhang, M.H.; Xu, Q.S.; Massart, D.L. Averaged and weighted average partial least squares. Anal. Chim. Acta 2004, 504, 279-289. [CrossRef]

61. Terrado, M.; Sabater, S.; Chaplin-Kramer, B.; Mandle, L.; Ziv, G.; Acuna, V. Model development for the assessment of terrestrial and aquatic habitat quality in conservation planning. Sci. Total Environ. 2016, 540, 63-70. [CrossRef] [PubMed]

62. Trisurat, Y.; Shirakawa, H.; Johnston, J.M. Land-Use/Land-Cover Change from Socio-Economic Drivers and Their Impact on Biodiversity in Nan Province, Thailand. Sustainability 2019, 11, 649. [CrossRef] [PubMed]

63. Ureta, J.C.; Clay, L.; Motallebi, M.; Ureta, J. Quantifying the Landscape's Ecological Benefits-An Analysis of the Effect of Land Cover Change on Ecosystem Services. Land 2021, 10, 21. [CrossRef]

64. Aneseyee, A.B.; Noszczyk, T.; Soromessa, T.; Elias, E. The InVEST Habitat Quality Model Associated with Land Use/Cover Changes: A Qualitative Case Study of the Winike Watershed in the Omo-Gibe Basin, Southwest Ethiopia. Remote Sens. 2020, 12, 1103. [CrossRef]

65. Nelson, E.; Mendoza, G.; Regetz, J.; Polasky, S.; Tallis, H.; Cameron, D.R.; Chan, K.M.A.; Daily, G.C.; Goldstein, J.; Kareiva, P.M.; et al. Modeling multiple ecosystem services, biodiversity conservation, commodity production, and tradeoffs at landscape scales. Front. Ecol. Environ. 2009, 7, 4-11. [CrossRef]

66. Yohannes, H.; Soromessa, T.; Argaw, M.; Dewan, A. Spatio-temporal changes in habitat quality and linkage with landscape characteristics in the Beressa watershed, Blue Nile basin of Ethiopian highlands. J. Environ. Manag. 2021, 281, 111885. [CrossRef]

67. Zhang, X.; Zhou, J.; Li, G.; Chen, C.; Li, M.; Luo, J. Spatial pattern reconstruction of regional habitat quality based on the simulation of land use changes from 1975 to 2010. J. Geogr. Sci. 2020, 30, 601-620. [CrossRef]

68. Hou, Y.; Li, B.; Mueller, F.; Chen, W. Ecosystem services of human-dominated watersheds and land use influences: A case study from the Dianchi Lake watershed in China. Environ. Monit. Assess. 2016, 188, 652. [CrossRef]

69. Getis, A.; Ord, J.K. The Analysis of Spatial Association by Use of Distance Statistics. Geogr. Anal. 1992, 24, 189-206. [CrossRef]

70. Ord, J.K.; Getis, A. Local spatial autocorrelation statistics: Distributional issues and an application. Geogr. Anal. 1995, 27, 286-306. [CrossRef]

71. Shaker, R.R.; Altman, Y.; Deng, C.; Vaz, E.; Forsythe, K.W. Investigating urban heat island through spatial analysis of New York City streetscapes. J. Clean. Prod. 2019, 233, 972-992. [CrossRef]

72. Lorilla, R.S.; Kalogirou, S.; Poirazidis, K.; Kefalas, G. Identifying spatial mismatches between the supply and demand of ecosystem services to achieve a sustainable management regime in the Ionian Islands (Western Greece). Land Use Policy 2019, 88, 104171. [CrossRef]

73. Tran, D.X.; Pla, F.; Latorre-Carmona, P.; Myint, S.W.; Gaetano, M.; Kieu, H.V. Characterizing the relationship between land use land cover change and land surface temperature. Isprs-J. Photogramm. Remote Sens. 2017, 124, 119-132. [CrossRef]

74. Boori, M.S.; Choudhary, K.; Paringer, R.; Kupriyanov, A. Spatiotemporal ecological vulnerability analysis with statistical correlation based on satellite remote sensing in Samara, Russia. J. Environ. Manag. 2021, 285, 112138. [CrossRef]

75. Choi, H.S.; Sohn, S.Y.; Yeom, H.J. Technological composition of US metropolitan statistical areas with high-impact patents. Technol. Forecast. Soc. Chang. 2018, 134, 72-83. [CrossRef]

76. Aguiar, L.L.; Manzato, G.G.; Rodrigues da Silv, A.N. Combining travel and population data through a bivariate spatial analysis to define Functional Urban Regions. J. Transp. Geogr. 2020, 82, 102565. [CrossRef]

77. Anselin, L. Local indicators of spatial association-LISA. Geogr. Anal. 1995, 27, 93-115. [CrossRef]

78. Di Giacinto, V.; Pagnini, M. Local and global agglomeration patterns: Two econometrics-based indicators. Reg. Sci. Urban Econ. 2011, 41, 266-280. [CrossRef]

79. Chen, L.; Wei, Q.; Fu, Q.; Feng, D. Spatiotemporal Evolution Analysis of Habitat Quality under High-Speed Urbanization: A Case Study of Urban Core Area of China Lin-Gang Free Trade Zone (2002-2019). Land 2021, 10, 167. [CrossRef]

80. Gaither, C.J.; Poudyal, N.C.; Goodrick, S.; Bowker, J.M.; Malone, S.; Gan, J. Wildland fire risk and social vulnerability in the Southeastern United States: An exploratory spatial data analysis approach. For. Policy Econ. 2011, 13, 24-36. [CrossRef]

81. Chen, B.; Wu, C.; Huang, X.; Yang, X. Examining the Relationship between Urban Land Expansion and Economic Linkage Using Coupling Analysis: A Case Study of the Yangtze River Economic Belt, China. Sustainability 2020, 12, 1227. [CrossRef]

82. Zhang, J.; Zhang, K.; Zhao, F. Research on the regional spatial effects of green development and environmental governance in China based on a spatial autocorrelation model. Struct. Chang. Econ. Dyn. 2020, 55, 1-11. [CrossRef]

83. Chen, L.; Ren, C.; Zhang, B.; Wang, Z.; Liu, M. Quantifying Urban Land Sprawl and its Driving Forces in Northeast China from 1990 to 2015. Sustainability 2018, 10, 188. [CrossRef]

84. Guo, Y.; Tong, L.; Mei, L. The effect of industrial agglomeration on green development efficiency in Northeast China since the revitalization. J. Clean. Prod. 2020, 258, 120584. [CrossRef]

85. Tian, J.; Wang, B.; Wang, S. Urban Land Use Efficiency and Its Coupling Relationship in the Three Provinces of Northeast China. Sci. Geogr. Sin. 2019, 39, 305-315. 
86. Baral, H.; Keenan, R.J.; Sharma, S.K.; Stork, N.E.; Kasel, S. Spatial assessment and mapping of biodiversity and conservation priorities in a heavily modified and fragmented production landscape in north-central Victoria, Australia. Ecol. Indic. 2014, 36, 552-562. [CrossRef]

87. Kim, D.; Seo, S.; Min, S.; Simoni, Z.; Kim, S.; Kim, M. A Closer Look at the Bivariate Association between Ambient Air Pollution and Allergic Diseases: The Role of Spatial Analysis. Int. J. Environ. Res. Public Health 2018, 15, 1625. [CrossRef]

88. Chica-Olmo, J.; Sari-Hassoun, S.; Moya-Fernandez, P. Spatial relationship between economic growth and renewable energy consumption in 26 European countries. Energy Econ. 2020, 92, 104962. [CrossRef]

89. Mao, D.; He, X.; Wang, Z.; Tian, Y.; Xiang, H.; Yu, H.; Man, W.; Jia, M.; Ren, C.; Zheng, H. Diverse policies leading to contrasting impacts on land cover and ecosystem services in Northeast China. J. Clean. Prod. 2019, 240, 117961. [CrossRef]

90. Zhang, Y.; Liu, Y.; Zhang, Y.; Liu, Y.; Zhang, G.; Chen, Y. On the spatial relationship between ecosystem services and urbanization: A case study in Wuhan, China. Sci. Total Environ. 2018, 637, 780-790. [CrossRef] [PubMed]

91. Zhang, L.; Hou, G.; Li, F. Dynamics of landscape pattern and connectivity of wetlands in western Jilin Province, China. Environ. Dev. Sustain. 2020, 22, 2517-2528. [CrossRef] 